\title{
Responses of benthic meiofauna to long-term, low-level additions of No. 2 fuel oil
}

\author{
Jeffrey B. Frithsen, Ragnar Elmgren* \& David T. Rudnick** \\ Marine Ecosystems Research Laboratory, Graduate School of Oceanography, University of Rhode Island, \\ Narragansett, Rhode Island 02882, USA
}

\begin{abstract}
Three experiments were conducted to investigate the responses of benthic meiofauna to long-term, low-level additions of $\mathrm{No} .2$ fuel oil in large $\left(13 \mathrm{~m}^{3}\right)$, outdoor tanks (mesocosms) containing sediment and sea water from Narragansett Bay, Rhode Island, USA. In the first experiment, an average water column oil concentration of $190 \mathrm{ppb}$ was maintained for $168 \mathrm{~d}$ followed by a $64 \mathrm{~d}$ period of no oil additions. During the second experiment, an average oil concentration of $90 \mathrm{ppb}$ was maintained for $122 \mathrm{~d}$. A $386 \mathrm{~d}$ period of no oil additions (Experiment III) followed Experiment Il. The abundances of metazoan meiofauna decreased during oil addition periods in Experiments I and II with the oil more extensively affecting the meiofauna in the first experiment. In both experiments, ostracods and harpacticoid copepods were the most sensitive metazoan groups. In contrast, abundances of protozoan meiofauna (foraminiferans and ciliates) were higher in the oiled mesocosms. Abundances of most meiofaunal groups returned to levels similar to the controls within 2 to 7 mo following the termination of oil additions. However, the abundances of kinorhynchs and halacarids remained depressed for more than 1 yr after the last oil addition, presumably due to residual oil in the sediments.
\end{abstract}

\section{INTRODUCTION}

Effects of petroleum hydrocarbons on meiofauna have been little studied compared to the number of investigations conducted on macrofauna. However, meiofauna could be better indicators of environmental stress than macrofauna due to their smaller size, shorter generation time, and a life-style almost always limited to the benthos (Fenchel 1967, Marcotte \& Coull 1974, Pequegnat 1975, Cantelmo \& Rao 1978, Boucher 1980). The majority of studies dealing with the effects of petroleum hydrocarbons on meiofauna have looked at communities affected by accidental oil spills from tankers or refineries (Rutzler \& Sterrer 1970, Wormald 1976, Giere 1979, Boucher 1980, Eskin 1980, RenaudMornant 1981, Bodin \& LeMoal 1982, Bodin \& Boucher 1983, Elmgren et al. 1983). Most of these studies suffer from lack of true controls and long-term data describing the natural temporal variations of meiofaunal com-

\footnotetext{
- Present address: Department of Zoology and Askö Laboratory, University of Stockholm, S-10691 Stockholm, Sweden - Present address: The Ecosystems Center, Marine Biological Laboratory, Woods Hole, Massachusetts 02543, USA
}

munities, elements needed to define effects that are caused by oil (Mann \& Clarke 1978, Teal \& Howarth 1984). The studies of Bodin \& Boucher (1983) and Elmgren et al. (1983) are noted exceptions. Additionally, the environmental concentrations of petroleum in the water column and the sediments are often unknown, especially at the beginning of these dramatic pollution events.

The purpose of this study is to detail the responses of benthic meiofauna to long-term, low-level inputs of No. 2 fuel oil such as may be present at the heads of urbanized estuaries and bays. An estimated $42 \%$ (National Academy of Science 1985) of all anthropogenic sources of oil entering the oceans enters these areas through municipal and industrial discharges, rivers, and land runoff from highways, parking lots, and industrial areas (Connell 1982, Hoffman et al. 1983). No. 2 fuel oil was chosen because it is a significant fraction of the mixture of petroleum hydrocarbons entering estuaries such as Narragansett Bay (Van Vleet \& Quinn 1978) and because of its large tanker volume in the northeastern United States. A synopsis of the structural and functional responses of the entire experimental ecosystem during this work has been presented by Oviatt et al. (1982), and preliminary 
benthic results reported in Elmgren et al. (1980a), Grassle et al. (1981), and Elmgren \& Frithsen (1982).

\section{METHODS}

Mesocosm description. Experiments were conducted in large, outdoor tanks (mesocosms, see Grice \& Reeve 1982) at the Marine Ecosystems Research Laboratory (MERL), University of Rhode Island, USA. The advantages and limitations of the use of experimental ecosystems in ecological research have been reviewed in Parsons et al. (1978), Giesy (1980) and Grice \& Reeve (1982).

The MERL mesocosms (Fig. 1) contain both seawater and sediments and simulate the Narragansett Bay ecosystem. Comparisons between data from control mesocosms and from Narragansett Bay demonstrate that the mesocosms simulate the natural ecosystem closely, with respect to hydrodynamic mixing and turbulence (Nixon et al. 1980), primary production (Oviatt et al. 1981), and nutrient concentrations and dynamics (Pilson et al. 1980). Phytoplankton species composition

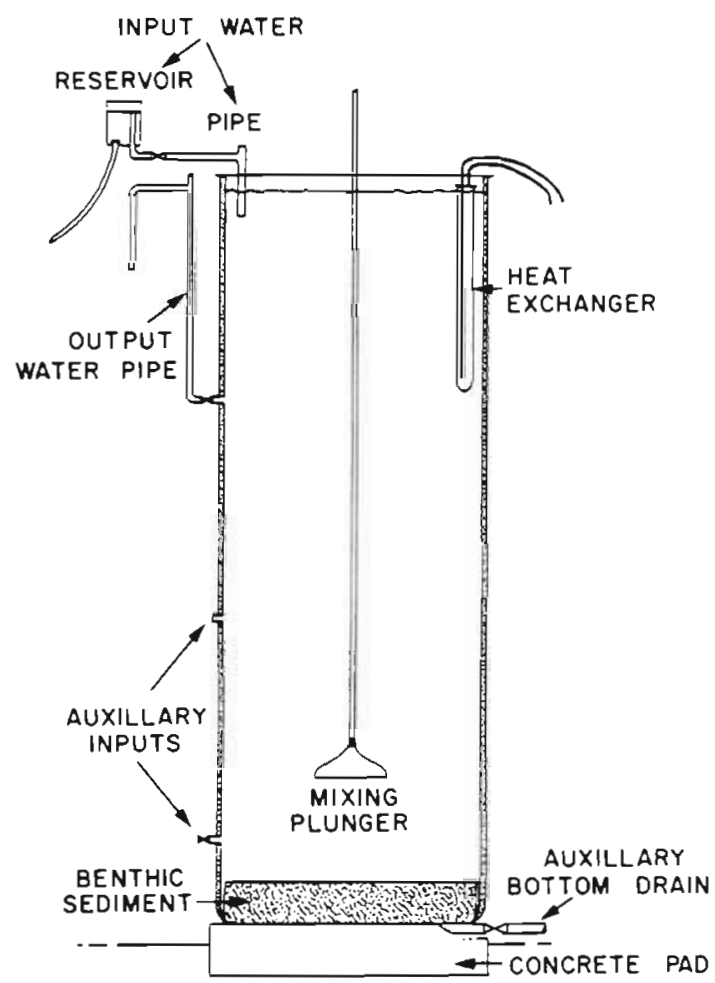

Fig. 1. MERL mesocosm. Height $550 \mathrm{~cm}$, inner diameter $182 \mathrm{~cm}$, seawater volume $13 \mathrm{~m}^{3}$, sediment depth $30 \mathrm{~cm}$. Turbulence created using a vertical plunger operating for 2 out of every $6 \mathrm{~h}$. All 6 mesocosms used were operated in a flowthrough mode with a water residency time of approximately $27 \mathrm{~d}$. This residency time matched the average water residency time calculated by Pilson (1985) for Narragansett Bay. Salinity was 28 to $30 \%$; temperature was maintained within $\pm 3^{\circ} \mathrm{C}$ of ambient bay temperature (see Fig. 2) and seasonal successional patterns between the bay and the tanks are similar (Vargo et al. 1982) and the structure and composition of control mesocosm benthic communities are similar to communities in the bay, although abundances in the mesocosms are generally lower (Grassle et al. 1981; Frithsen 1984).

Experimental outline. Three experiments were conducted using the water accommodated fraction of No. 2 fuel oil (Table 1). The composition of this fraction have been reported by Gearing et al. (1979). In the first experiment (Experiment I), oil was added twice weekly (Gearing et al. 1979) yielding an average total water column hydrocarbon concentration of $190 \mu \mathrm{g} \mathrm{l}^{-1}$ (ppb) (Oviatt et al. 1980). In the second experiment (Experiment II), using new sediments, twice weekly additions of oil were made yielding an average water column concentration of $90 \mu \mathrm{g} \mathrm{l}^{-1}$ (Oviatt et al. 1982). A period without oil additions followed each experiment in order to measure the recovery, if any, of affected ecosystem parameters. The recovery period after Experiment I was short (64 d), whereas the recovery period after Experiment II was more than a year (386 d) and was referred to as Experiment III, as in Oviatt et al. (1982). In all experiments, 3 mesocosms served as controls and 3 mesocosms received oil additions and were used in the recovery periods. All 6 mesocosms received daily inputs of water from Narragansett Bay to maintain a water residency time of $27 \mathrm{~d}$.

Analyses. In Experiment I, ten $4.15 \mathrm{~cm}^{2}$ cores were taken from each of 2 sets (control and oiled) of mesocosms using a remote, thin-walled, metal corer attached to a long pole. This remote corer was replaced by a flow-through remote corer $\left(5.06 \mathrm{~cm}^{2}\right)$ in January 1978 in order to more accurately sample the sediment's surface flocculent layer (Frithsen et al. 1983). Each core was sectioned ( 0 to $2 \mathrm{~cm}$ and 2 to $6 \mathrm{~cm}$ depth horizons) and individually preserved in $4 \%$ buffered formaldehyde. Macrofauna (organisms retained on a $300 \mu \mathrm{m}$ sieve) were analyzed by J. F. Grassle's laboratory at the Woods Hole Oceanographic Institution.

Meiofauna, here defined as metazoans and foraminiferans that pass through a $500 \mu \mathrm{m}$ sieve, and are retained on a $40 \mu \mathrm{m}$ sieve. Since there was an overlap between the macrofauna definition used by Grassle's laboratory and the meiofauna definition used at MERL in the 300 to $500 \mu \mathrm{m}$ range, all specimens on the $300 \mu \mathrm{m}$ sieve commonly considered to be macrofauna (polychaetes, oligochaetes, bivalves, gastropods, turbellarians) were included in the macrofauna total abundance and all other groups were considered meiofauna. All specimens passed through the $300 \mu \mathrm{m}$ and retained by smaller sieves were considered meiofauna.

The quantitative analysis of benthic meiofauna is much more time consuming than the analysis of mac- 
Table 1. Outline of oil experiments

\begin{tabular}{|c|c|c|c|}
\hline & $\begin{array}{c}\text { Experiment I } \\
1977\end{array}$ & $\begin{array}{c}\text { Experiment II } \\
1978\end{array}$ & $\begin{array}{c}\text { Experiment III } \\
1978-1979\end{array}$ \\
\hline Oil addition period (d) & Feb 14 - Aug $1(168)$ & Mar 6 - Jul 6 (122) & None \\
\hline Recovery period (d) & Aug 1 -Oct 4 (64) & None & Jul $6-$ Jul 27 (386) \\
\hline Oil added & $108 \mathrm{~g}^{\left(43 \mathrm{~g} \mathrm{~m}^{-2}\right)}$ & $40 \mathrm{~g}\left(16 \mathrm{~g} \mathrm{~m}^{-2}\right)$ & None \\
\hline $\begin{array}{l}\text { Mean water column oil } \\
\text { concentration } \\
\text { Percent of oil in Sediment }\end{array}$ & $190 \mathrm{ppb}$ & $90 \mathrm{ppb}$ & $7 \mathrm{ppb}$ \\
\hline at end of experiment & $?$ & 50 & $10-20$ \\
\hline Tanks per treatment & 3 & 3 & 3 \\
\hline $\begin{array}{l}\text { Number of meiofaunal samples } \\
\text { per oil addition period } \\
\text { Number of meiofaunal samples }\end{array}$ & 6 & 4 & - \\
\hline per recovery period & 3 & - & 4 \\
\hline Temperature range & $1-23^{\circ} \mathrm{C}$ & $0-21^{\circ} \mathrm{C}$ & $0-23^{\circ} \mathrm{C}$ \\
\hline
\end{tabular}

rofauna. Therefore, all 10 cores from a single mesocosm tank were combined to form 1 composite sample per tank. This left 3 replicates per treatment with no measurement of within tank variability. Only the 0 to $2 \mathrm{~cm}$ sedimentary horizons were regularly analyzed for meiofauna. Eight of the deeper, 2 to $6 \mathrm{~cm}$ sedimentary horizons were examined to compare vertical zonation patterns between treatments

The decantation procedure of Uhlig et al. (1973) and the subsampling methods of Elmgren (1973) were used in the quantitative analysis of meiofauna. A succession of sieves $(300,200,100$ and $40 \mu \mathrm{m})$ was used to study size distribution trends through the experiment. All specimens were identified to the lowest possible, easily recognizable taxonomic group. Further details of the methodology and a complete tabulation of the size fractionated abundance data may be found in Frithsen (1984).

Procedures used for sediment hydrocarbon measurements (Fig. 2) are described in Wade \& Quinn (1980) and Gearing et al. (1978, 1979, 1980). Internal standards were added to all samples before extraction. Oil in the water column was extracted by shaking with petroleum ether or methylene chloride. Oil in sediments was extracted and saponified by refluxing with a mixture of methanolic $\mathrm{KOH}$ and benzene. Extracts were purified by thin layer (silica gel G) and/or column chromatography. Samples were separated into 2 fractions: a $F_{1}$ fraction containing aliphatic and alicyclic hydrocarbons, and a $\mathrm{F}_{2}$ fraction containing aromatic and polyolefinic hydrocarbons. Hydrocarbons were analyzed by gas chromatography using packed FFAP, packed SP1000 or glass capillary SE-52 columns.

Statistics. The non-parametric Wilcoxon's rank-sum test (Snedecor \& Cochran 1967) was used. Treatments were considered significantly different at the alpha 0.1 level if all 3 replicates from 1 treatment were greater than all 3 replicates from the other treatment $(2$-tailed test). The mean, range, and individual values for each mesocosm were plotted (Fig. 3 to 5) so that significant changes could be discerned between treatments for each point in time. A non-parametric, multivariate analysis of variance (SAS 1982) was conducted for all groups using data collected during the oil addition periods only, and separately for the recovery periods.

\section{RESULTS}

\section{Experiment I}

Oil behavior

Almost no oil accumulation was measured in sediments during the colder winter and early spring months (Fig. 2). After an initial lag phase and with an

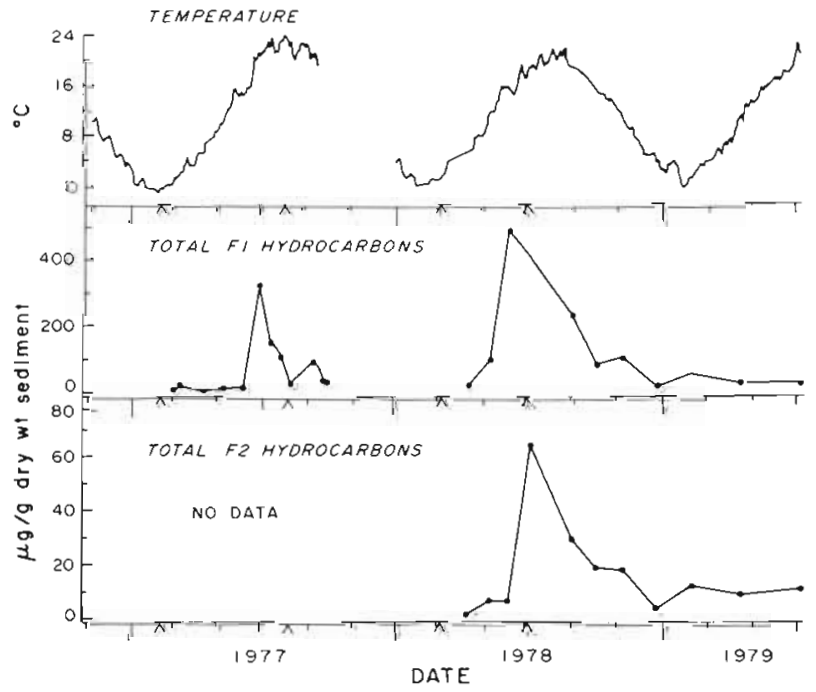

Fig. 2. Mesocosm temperatures expressed as a $3 \mathrm{~d}$ running average. Oil concentrations in sediments $(0$ to $1 \mathrm{~cm}), F_{1}$ (aliphatic and alicyclic) and $F_{2}$ (aromatic and polyolefinic) hydrocarbons. Carets below horizontal axis show the beginning and end of each oil addition period 
increase in water temperature (Fig. 2), sedimentary oil concentrations rapidly increased until the end of the oil addition period in early August. Sediment hydrocarbons then decreased exponentially following the termination of oil additions (Oviatt et al. 1982). The temporal pattern of sediment hydrocarbon concentrations was similar for both the aliphatic $\left(F_{1}\right)$ and aromatic $\left(F_{2}\right)$ fractions. However, the differential water solubilities of fuel oil hydrocarbons resulted in the deposition of a relatively greater proportion of aliphatic hydrocarbons than aromatic hydrocarbons (Gearing et al. 1980). The rate of removal of waterborne oil due from all processes increased with temperature (Gearing \& Gearing 1982a, b).

The rapid increase of sediment hydrocarbon concentrations measured in the early spring may have been an artifact of sampling since more care was taken to sample and analyze flocculent detritus at the surface of the sediment starting in June (Wade \& Quinn 1980). Measured sediment hydrocarbon concentrations during this first experiment were considered minimal esti- mates since the coring device used did not adequately collect the surface floc containing much sedimented oil (Gearing et al. 1980, Wade \& Quinn 1980).

\section{Metazoan meiofaunal responses}

The abundance of most metazoan groups was lower in the oiled tanks than in control tanks. Within $37 \mathrm{~d}$ after the first oil addition, the abundance of all meiofauna in the oiled tanks was $27 \%$ lower than in the controls, despite initially higher densities the previous November (Fig. 3). This difference became significant by April 20 and remained so, with the exception of May, throughout the oil addition period (Feb 14 to Aug 1), and for $30 \mathrm{~d}$ after the oil additions had ceased.

Since $77 \%$ of all meiofauna in both the control and oiled tanks were nematodes, the dynamics of this group was similar to that of the total meiofauna (Fig. 3). Additionally, the size distribution of nematodes in the oiled tanks changed compared to

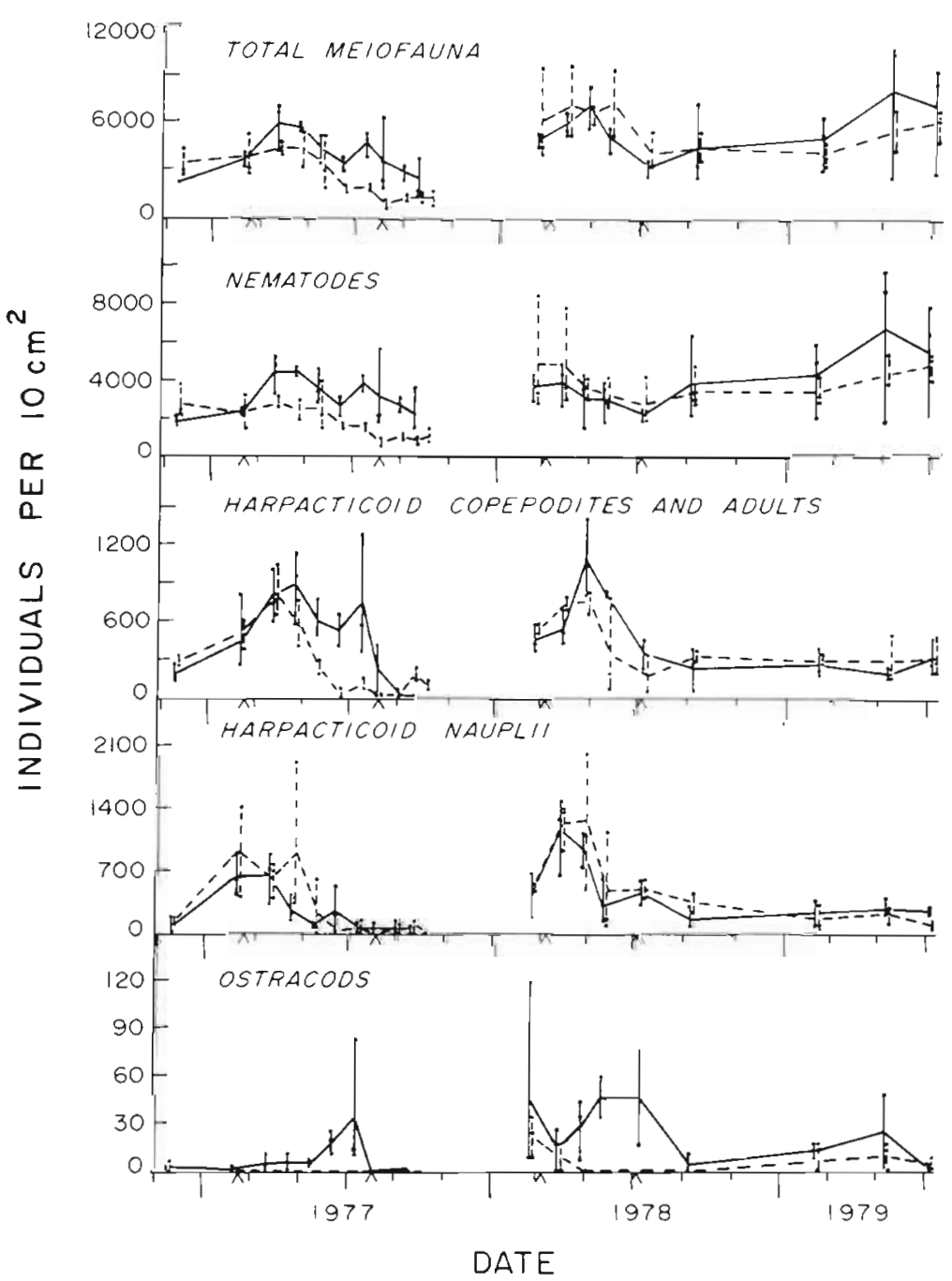

Fig. 3. Abundances of total meiofauna, nematodes, harpacticoid copepodites and adults, harpacticoid nauplii, and ostracods. Individual, range, and mean values given for the control (solid line) and oiled (broken line) mesocosms. Carets below horizontal axis show the beginning and end of each oil addition period. Abundances can be converted to number $\mathrm{m}^{-2}$ by multiplying by 1,000 
that in the controls during the oil addition period. Nematodes in the oiled tanks were larger than those in the controls as indicated by the percentage of nematodes enumerated in each size fraction (Table 2). During the recovery period, there was also a greater proportion of large nematodes in the oiled tanks.

Harpacticoid copepods were the second most abundant meiofaunal group sharply decreasing abundance in the oiled mesocosms (Fig. 3). This response occurred later than for the nematodes. Temporal changes in abundance were similar to the controls during the first month of oil additions, but declined quickly in April becoming significantly lower by May. The difference between treatments was significant until the beginning of August when control tank abundance also declined. An apparent recovery of the harpacticoids was observed after oil additions had ceased when harpacticoid abundance in the oiled tanks was greater than controls in September (Fig. 3; Table 2). Harpacticoid nauplii abundance (Fig. 3) was not significantly affected by the oil additions. Harpacticoid copepodites and adults were generally larger in the oiled tanks than in the controls (Table 2) during the oil addition period, but not during the recovery period of Experiment I.

The meiofaunal group which showed the most dramatic effect due to the oil additions was the ostracods (Fig. 3). Within $37 \mathrm{~d}$ of the first oil addition, no ostracods were found in 2 of the 3 oiled tanks and only 2 individuals (representing 500 indiv. $\mathrm{m}^{-2}$ ) were present in samples from the third oiled tank. Thereafter, no ostracods were found in any of the oiled tanks. A decline in the control tanks in August caused the differences between treatments to be non-significant for the remainder of the experiment. Similar late summer declines were observed in control tanks during 1978 and 1979.

Other metazoan groups were also significantly affected by the oil additions (Table 2). Kinorhynchs (Fig. 4) were less abundant in the oiled tanks during both the oil addition period and the short recovery period. Fewer turbellarians (Fig. 4) were in the oiled tanks only during the oil addition period, showing a return to control tank abundances during the recovery period. The abundance of halacarids (Fig. 4) was not significantly different between treatments during the oil addition period. However, these organisms were absent from the oiled mesocosms during the recovery period.

The only metazoan meiofaunal group to increase in the oiled mesocosms was juvenile polychaetes (Fig. 5; Table 2). Polychaete abundances in the oiled tanks was significantly greater than abundances in the control tanks during the oil addition period. This result is in contrast to those reported for the macrofauna by Grassle et al. (1981) where the capitellid Mediomastus

Table 2 . Results of univariate analysis of variance using ranked data

\begin{tabular}{|c|c|c|c|c|}
\hline & \multicolumn{2}{|c|}{ Experiment I } & \multirow{2}{*}{$\begin{array}{l}\text { Experiment II } \\
\text { Oil addition }\end{array}$} & \multirow{2}{*}{$\begin{array}{c}\text { Experiment III } \\
\text { Recovery }\end{array}$} \\
\hline & Oil addition & Recovery & & \\
\hline Total meiofauna & $c>0 \cdots$ & $\mathrm{C}>\mathrm{O} \cdots$ & NS & NS \\
\hline Nematodes & $\mathrm{C}>\mathrm{O} \cdots$ & $\mathrm{C}>\mathrm{O} \cdots$ & NS & NS \\
\hline Desmoscolecidae & NS & NS & NS & NS \\
\hline Percent on $40 \mu \mathrm{m}$ sieve & $\mathrm{C}>\mathrm{O} \cdots$ & NS & NS & NS \\
\hline Percent on $100 \mu \mathrm{m}$ sieve & $\mathrm{O}>\mathrm{C}$ & NS & NS & NS \\
\hline Percent on $200 \mu \mathrm{m}$ sieve & $\mathrm{O}>\mathrm{C} \cdot \cdot$ & NS & NS & NS \\
\hline Percent on $300 \mu \mathrm{m}$ sieve & $\mathrm{O}>\mathrm{C} \cdots$ & $\mathrm{O}>\mathrm{C} \cdots$ & NS & $\mathrm{C}>\mathrm{O} \cdots$ \\
\hline \multicolumn{5}{|l|}{ Harpacticoid copepods } \\
\hline Adults and copepodites & $c>0 \cdots$ & $\mathrm{O}>\mathrm{C} \cdots$ & $C>0 \cdots$ & NS \\
\hline Percent on $40 \mu \mathrm{m}$ sieve & $\mathrm{C}>\mathrm{O} \cdots$ & NS & NS & NS \\
\hline Percent on $100 \mu \mathrm{m}$ sieve & NS & NS & NS & NS \\
\hline Percent on $200 \mu \mathrm{m}$ sieve & $\mathrm{O}>\mathrm{C}$ & NS & $\mathrm{O}>\mathrm{C} \cdot \cdot$ & NS \\
\hline Percent on $300 \mu \mathrm{m}$ sieve & NS & NS & NS & $\mathrm{O}>\mathrm{C} \cdots$ \\
\hline Dead Adults and copepodites & $\mathrm{O}>\mathrm{C}$ & NS & $\mathrm{O}>\mathrm{C}$ & NS \\
\hline Nauplii & NS & NS & NS & NS \\
\hline Ostracods & $c>0 \cdots$ & NS & $\mathrm{c}>\mathrm{O} \cdots$ & NS \\
\hline Turbellarians & $\mathrm{C}>\mathrm{O} \cdots$ & NS & NS & NS \\
\hline Kinorhynchs & $\mathrm{C}>\mathrm{O} \cdots$ & $\mathrm{C}>\mathrm{O} \cdots$ & NS & $\mathrm{C}>\mathrm{O} \cdots$ \\
\hline Halacarids & NS & $\mathrm{C}>\mathrm{O} \cdots$ & NS & $\mathrm{C}>\mathrm{O} \cdots$ \\
\hline Foraminiferans & $\mathrm{O}>\mathrm{C} \cdots$ & $\mathrm{O}>\mathrm{C} \cdots$ & $\mathrm{O}>\mathrm{C} \cdots$ & NS \\
\hline Ciliates & $\mathrm{O}>\mathrm{C} \cdots$ & NS & $\mathrm{O}>\mathrm{C} \cdots$ & NS \\
\hline Juvenile polychaetes & $\mathrm{O}>\mathrm{C}$ & NS & NS & NS \\
\hline
\end{tabular}




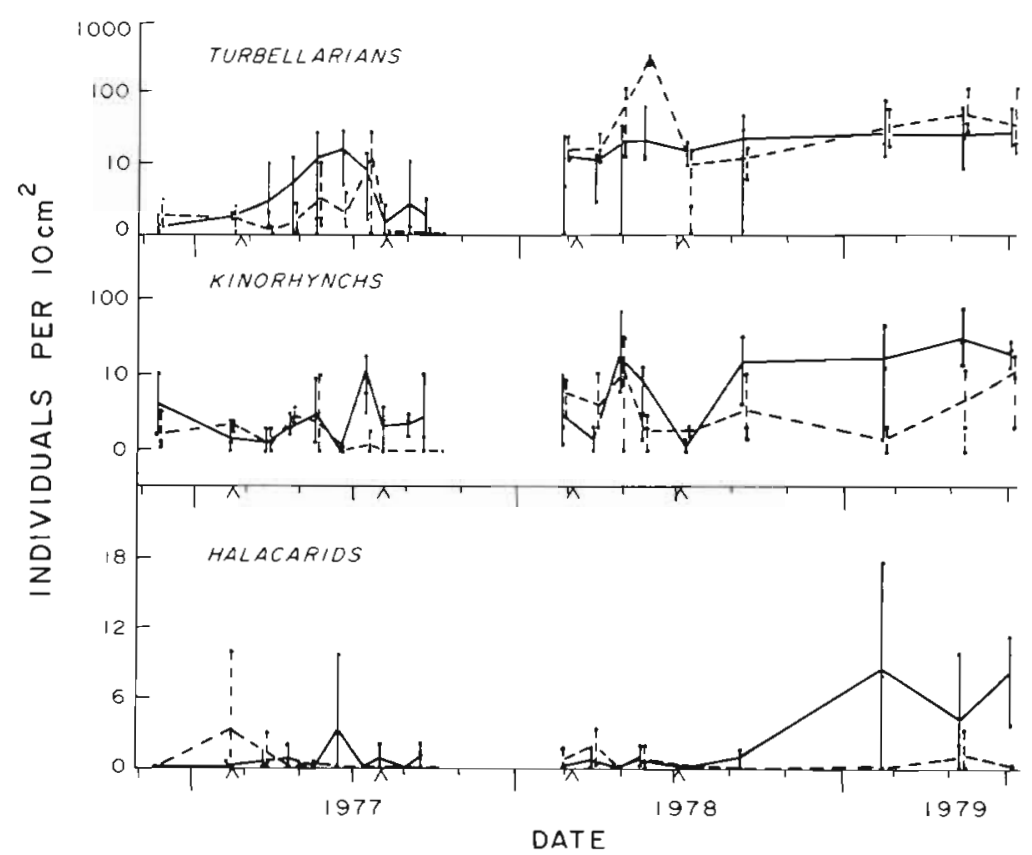

Fig. 4. Abundances of turbellarians, kinorhynchs and halacarids. Legend as in Fig. 3

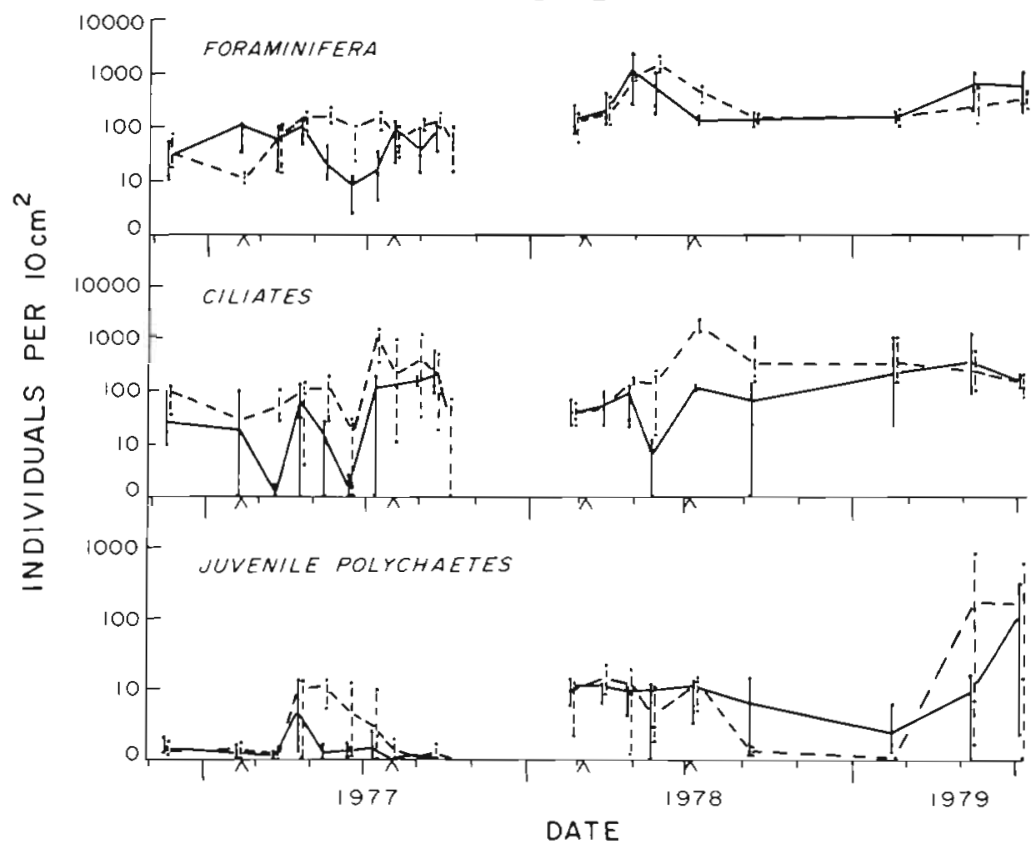

Fig. 5. Abundances of foraminiferans, ciliates, and juvenile polychaetes. Legend as in Fig. 3

ambiseta, decreased shortly after the start of the oil additions and remained depressed throughout the experiment. Only the rarer polychaetes Nereis virens and Chaetozone sp. increased abundance in the oiled tanks.

\section{Protozoan meiofaunal responses}

In contrast to most metazoan groups, the number of protozoan meiofauna increased in the oiled tanks. Foraminiferans (Fig. 5) showed sharply and significantly increased abundances. The difference between treatments might have been greater had foraminiferan abundance not been significantly lower in the tanks to be oiled immediately before the start of the addition period. Significant differences between treatments were evident from May to July.

Although foraminiferans were the only protozoan group reliably enumerated with the methodologies used, large, robust ciliates retained by a $40 \mu \mathrm{m}$ sieve and able to withstand preservation and sieving without fragmenting were also counted, but not included in the calculation of total meiofaunal abundance. These ciliates were significantly more abundant in the oiled tanks compared to the controls (Fig. 5; Table 2). This 
result was corroborated by Elmgren et al. (1980a) with direct counts of ciliates in live samples.

\section{Depth distribution}

Surface sediments and sediment surface floc had the highest concentration of oil (Wade \& Quinn 1980) since most of the oil reached the sediment associated with settling particles. To test the hypothesis that meiofauna would use deeper sediments as refuge from high oil concentrations in surface sediments, 6 samples ( 3 from each treatment) from the 2 to $6 \mathrm{~cm}$ horizons were analyzed during the oil addition period. The proportion of all $(0$ to $6 \mathrm{~cm})$ meiofauna found in the 2 to $6 \mathrm{~cm}$ horizon was not significantly different between treatments using a non-parametric, multivariate analysis of variance (SAS 1982).

\section{Experiment II}

\section{Oil behavior}

The temporal pattern of oil accumulation in the surface sediments during the second oil addition period appeared similar to the first oil addition period. The initial lag period during which there was little or no accumulation of oil was, however, shorter presumably due to a change to a corer that more efficiently sampled surface floc material. This lag period was followed by a increase in oil concentrations with rising temperatures. The fractionation of oil in the sediments was similar during the 2 oil addition experiments with relatively more of the aliphatic hydrocarbons found on particulates and sediments than were present in the water column (Gearing et al. 1980).

\section{Metazoan meiofaunal responses}

The lower hydrocarbon concentrations during the second oil addition period in both the water column and, presumably, the sediments caused fewer effects than were observed during the first oil addition period (Oviatt et al. 1982). Oil additions had no effect at all on the total abundance of meiofauna (Fig. 3; Table 2) or nematodes (Fig. 3). Nematodes made up a smaller percentage ( $57 \%$ vs. $77 \%$ ) of the total meiofaunal abundance during the second oil addition period.

Harpacticoid copepods were sensitive to oil in both experiments. Copepodites and adults (Fig. 3; Table 2) decreased in the oiled tanks whereas nauplii were not affected. Size fractionated data indicated that the harpacticoids in the oiled tanks were generally larger than those in the controls.

The most oil sensitive group during Experiment II was again the ostracods (Fig. 3). Within $50 \mathrm{~d}$ of the start of additions, significant differences were seen between the control and oiled tanks. Ostracods remained at low densities in all oiled tanks until September when no individuals were found in any of the oiled tanks. However, ostracod abundances in the control tanks also fell during the summer and no ostracods were found in 2 of the 3 controls in September.

No other metazoan meiofaunal groups were significantly affected by the presence of oil during the second oil addition period (Table 2). However, there was a short-term tendency for elevated turbellarian abundances in the oiled tanks.

\section{Protozoan meiofaunal responses}

The abundance of protozoan meiofauna was significantly higher in the oiled tanks, compared to controls, paralleling results from Experiment 1 (compare Table 2). Foraminiferans (Fig. 5) made up 14\% of all meiofauna in the control tanks during the oil addition period of Experiment II, and $18 \%$ of all meiofauna in the oiled tanks indicating the response of this group to the presence of oil. Ciliate abundance also increased significantly during Experiment II (Fig. 5; Table 2).

\section{Experiment III - Long term recovery}

\section{Oil behavior}

Water-column oil concentrations decreased from $90 \mathrm{ppb}$ to background hydrocarbon levels within $1 \mathrm{wk}$ after the last oil addition. However, sediment oil concentrations decreased much more slowly and were still $80 \mu \mathrm{g} \mathrm{g}^{-1}$ above background concentrations in July 1979 .

\section{Meiofaunal responses}

Most groups affected during the oil addition period of Experiment II recovered to control tank abundances within 2 mo of the termination of oil additions. Ciliates were the exception: their abundance in the oiled tanks was not similar to the controls until February 1979. The size distribution of the nematodes and harpacticoids (Table 2) was not, however, similar during the recovery period. Nematodes were larger and harpacticoid copepodites and adults were smaller in the control tanks during this period.

The abundances of kinorhynchs and halacarids in the oiled tanks did not significantly differ from the controls during the oil addition period of Experiment II, but were lower during the 13 mo long recovery period of Experiment III (Fig. 5; Table 2), presumably due to the residual presence of oil in the sediments (Fig. 2). Con- 
trol tank populations of both groups increased during Experiment III while oil tank populations remained depressed. The consistently low abundance of a single control mesocosm (Tank 1) caused the overlap of treatment ranges for kinorhynchs during Experiment III.

Nematodes may also have been affected by the residual oil even though significant treatment effects were not observed. A single control mesocosm (Tank 1) consistently had the lowest abundance of any mesocosm (control or oiled) from March 1978 to the end of Experiment III. Nematode abundances in all 3 oiled tanks were less than the 2 remaining control tanks from February 1979 to the end of the Experiment (Fig. 3).

\section{DISCUSSION}

The experimental results demonstrated that small amounts of No. 2 fuel oil can cause rapid alterations to the structure of benthic meiofaunal communities. Significant effects were observed during Experiment II when approximately $16 \mathrm{~g}$ oil $\mathrm{m}^{-2}$ was added over a $122 \mathrm{~d}$ period. The more sensitive meiofaunal groups responded to water column concentrations as low as $90 \mu \mathrm{g} \mathrm{l}^{-1}$ and sediment concentrations as low as $940 \mathrm{\mu g} \mathrm{g}^{-1}$ dry weight sediment.

\section{Metazoan meiofauna - main effects}

Most metazoan meiofaunal groups showed decreased abundance in the presence of oil, especially during the higher oil dosage of Experiment I. Rapid decreases in abundances (e.g. nematodes, ostracods) were most likely caused by the direct toxic effects from the sedimented oil fractions whereas delayed decreases (e.g. halacarids) were most likely caused by the sub-lethal effects of sedimented oil and byproducts from the decomposition and alteration of sedimented oil. Further evidence for the direct toxic effects of the added oil came from the number of 'dead' (lightly stained individuals and empty carapaces) harpacticoids that were found in samples collected during the oil addition periods (Table 2). Field investigations following accidental oil spills have also attributed rapid declines to the direct toxic effects of petroleum (Wormald 1976, Sanders et al. 1980. Elmgren et al. 1983), and laboratory studies have demonstrated the toxicity of many types of petroleum hydrocarbons (Neff \& Anderson 1981) and especially aromatic hydrocarbons which made up $25 \%$ (by weight) of the No. 2 fuel oil used (Gearing et al. 1979).

The most sensitive group of benthic organisms in this study was the crustaceans, specifically ostracods and harpacticoid copepods. The response of the ostracods was similar to that of macrofaunal amphipods (Ampelisca) described by Elmgren \& Frithsen (1982) and Oviatt et al. (1982). Both the ostracods and amphipods were eliminated from the oiled tanks in Experiment I and severely reduced in Experiment II. The responses of both groups to the 2 oil addition experiments were rapid, occurring in approximately $1 \mathrm{mo}$.

Several other laboratory and field investigations have shown that amphipods are sensitive to petroleum hydrocarbons (Linden 1976, Percy 1977, Cabioch et al. 1982, Sanders et al. 1980, Elmgren et al. 1983). However, the sensitivity of ostracods to oil has been examined rarely. Studies of the Tsesis oil spill in the Baltic Sea (Elmgren et al. 1980b, Elmgren \& Frithsen 1982, Elmgren et al. 1983), the 'Amoco Cadiz' oil spill (Chasse 1978), and the MERL studies (Elmgren et al. 1980a, Grassle et al. 1981, Elmgren \& Frithsen 1982, Oviatt et al. 1982) have shown that ostracods are particularly sensitive to petroleum hydrocarbons.

Harpacticoid copepods were not as sensitive as the ostracods, maintaining a small assemblage in the oiled tanks during Experiment I and II, and quickly returning to abundances similar to the controls after the oil addition period. Rapid recovery of harpacticoids to normal abundances following exposure to petroleum has been noted by Elmgren et al. (1983) and Bodin \& Boucher (1983). However, long-term effects on the seasonal cycle of harpacticoids following the Amoco Cadiz' spill (Bodin \& Boucher 1983) indicated that studies of abundance and species composition over a single annual cycle may not be adequate to address the recovery of perturbed communities.

\section{Metazoan meiofauna - effects on recruitment}

The separate enumeration of meiofauna retained by a series of sieves allowed the size distributions of major groups within the meiofauna to be approximated. The finding that harpacticoids and nematodes in the oiled tanks were generally larger than in the control tanks suggested that the recruitment success of these 2 groups was, in some way, affected so that fewer juveniles, proportional to the total community, were present in the oiled tanks. Community size structure can also change due to changes in species composition of dominants (Hicks 1982, Boucher 1980, Alongi et al. 1983). However, the size distribution differences between treatments could not be due solely to changes in species composition since changes were observed in the smallest fraction ( 40 to $100 \mu \mathrm{m}$ ) that would include predominantly juvenile forms. Fleeger \& Chandler (1983) demonstrated only small changes to harpacticoid community structure due to the presence of oil. 
The observation that harpacticoid nauplii were not affected by the oil additions indicated that harpacticoids in the oil tanks were producing viable nauplii. The size distribution data (fewer copepodites of small size), however, suggests that these nauplii were less successful at metamorphosis than nauplii in the control tanks. Metamorphosis has been identified as a sensitive stage for other crustaceans (Hyland \& Schneider 1976).

A similar pattern was observed for polychaetes where juvenile polychaetes enumerated in the meiofaunal size range increased abundance in the presence of oil. However, macrofaunal studies (Grassle et al. 1981) have shown that most polychaetes decreased abundance in the presence of oil indicating poor growth of juveniles or survivorship of adults.

\section{Protozoan meiofauna}

The only meiofaunal group to increase abundance during the oil addition periods of both Experiment I and Experiment II were protozoan meiofauna (foraminiferans, ciliates). The added No. 2 fuel oil was not lethal to protozoan meiofauna at the concentrations measured during our experiments and thriving protozoan meiofaunal communities were maintained even in the absence of an active metazoan community.

The increase in the abundance of protozoan meiofauna in the oiled mesocosms was attributable to both the release of the protozoans from competition, predation, or disturbance pressures from the metazoans (Elmgren et al. 1980a), and the overall increase in food at the sediment surface. Predation and disturbance pressures on the protozoans were expected to be less due to the depressed abundance of nearly every metazoan group (Oviatt et al. 1982). Competition for available food resources would also be less. At the same time, the amount of food potentially available in the sediments probably increased due to increases in primary production (Oviatt et al. 1982), decreases in zooplankton biomass (Oviatt et al. 1982), increases in benthic diatom standing stocks (Elmgren et al. 1980, Langlois 1980), and increases in oil degrading sediment bacteria. Although oil degrading sediment bacteria were not measured during the MERL experiments, Davis et al. (1979) found increases in water column bacteria during the experiment, and Gearing et al. (1980) estimated that 80 to $90 \%$ of the oil in the sediments was affected by microbial biodegradation.

\section{Meiofaunal vs macrofaunal effects}

The hypothesis that meiofauna are more sensitive indicators of oil stress than macrofauna (Pequegnat
1975. Boucher 1980) was not fully supported by the results from this study. In Experiment I, the abundance of nematodes (the dominant meiofaunal group) was significantly lower in the oiled mesocosms compared to the controls within $37 \mathrm{~d}$ of the start of the oil addition period, whereas none of the dominant macrofaunal species showed a significant difference until the warm summer $121 \mathrm{~d}$ into the oil addition period (Grassle et al. 1981). However, amphipods - a macrofaunal group that has been previously noted due to its sensitivity to oil - were nearly absent from the mesocosms during Experiment I. During Experiment II, when amphipods were present, effects were seen in the macrofauna as rapidly as in the meiofauna. Therefore, we question whether meiofauna are necessarily more sensitive indicators of pollution stress at least in sublittoral, mud environments. Meiofauna may still be the most suitable indicators in meiofauna dominated communities, such as those in sandy beaches (McLachlan \& Hardy 1982)

\section{Recovery time scales}

Two of the major conclusions that have come from synoptic studies of petroleum effects on ecosystems (Elmgren et al. 1980a, Kineman et al. 1980, Oviatt et al. 1982) are that the presence of fuel oil causes widespread changes in the abundance, biomass, and functioning of communities throughout marine ecosystems, and that recovery from the effects of petroleum hydrocarbons is much faster for plankton communities than for benthic communities. While hydrocarbons in the water column are diluted and dispersed, sediments are a sink for hydrocarbons due to direct sinking, and the adsorption and incorporation of oil onto particles in the water column that then sink (National Academy of Science 1975, Gearing et al. 1980, Wade \& Quinn 1980, Boehm et al. 1982). Benthic organisms in such ecosystems are surrounded by petroleum contaminated sediment where the contaminant removal processes (burial and biodegradation) are slow (Atlas 1981, Boehm et al. 1982, Gearing \& Gearing 1983).

Many of the meiofaunal groups affected by the addition of oil in Experiment I did not recover to normal abundances in the short recovery period following oil addition abatement. Even though water column oil concentrations dramatically decreased and sediment oil concentrations slowly declined, components of the No. 2 fuel oil that remained in the sediments were presumably still toxic. Most meiofaunal groups returned rapidly to normal abundances during the Experiment III period of no oil additions due to the longer period allowed at high summer temperatures, and the lower oil concentrations used during Experiment II. Past studies (McLachlan \& Harty 1982, 
Table 3. Hydrocarbon concentrations in coastal sediments

\begin{tabular}{|c|c|c|c|}
\hline Location & Type of hydrocarbons & $\begin{array}{l}\text { Concentration } \\
\mu \mathrm{g} / \mathrm{g}^{-1} \text { dry wt }\end{array}$ & Source \\
\hline \multirow[t]{2}{*}{ Providence River, Rhode Island } & Total & $450-5410$ & Van Vleet \& Quinn (1977) \\
\hline & Total & $500-5700$ & Fanrington \& Quinn (1973) \\
\hline North Narragansett Bay, RI & Total & $460-1070$ & Farrington \& Quinn (1973) \\
\hline \multirow[t]{4}{*}{ Mid-Narragansett Bay, RI } & Total & $350-440$ & Farrington \& Quinn (1973) \\
\hline & Total & 146 & Gearing et al. (1979) \\
\hline & F1, Saturated & 173 & Wade \& Quinn (1979) \\
\hline & F2, Aromatic & 12 & Wade \& Quinn (1979) \\
\hline \multirow[t]{2}{*}{ South Narragansett Bay, RI } & Total & $50-60$ & Farrington \& Quinn (1973) \\
\hline & Total & 72 & Hurtt \& Quinn (1979) \\
\hline Rhode Island Sound & Total & $1-56$ & Boehm \& Quinn (1978) \\
\hline Georges Bank, NE Atlantic & Total & $2-20$ & Boehm et al. (1979) \\
\hline Casco Bay, Maine & Polycyclic aromatic & $0.2-14.4$ & Larsen et al. (1983) \\
\hline \multicolumn{4}{|l|}{ Buchan Gulf + Scott Inlet, } \\
\hline Baffin Island & Petroleum & $25-90$ & Levy \& Ehrhardt (1981) \\
\hline \multirow{2}{*}{ Raritan Bay, NJ } & Total & $2-1098$ & Stainken (1979) \\
\hline & Total C15+ & $72-3672$ & Koons \& Thomas (1979) \\
\hline \multirow[t]{2}{*}{ New York Bight } & Total & $500-3000$ & Farrington \& Tripp (1977) \\
\hline & Total C15+ & $102-6530$ & Koons \& Thomas (1979) \\
\hline Hudson-Raritan Bays & Petroleum & $26-9890$ & Connell (1982) \\
\hline Colgate Creek, Baltimore Harbour & Petroleum & 3200 & Walker et al. (1975) \\
\hline Delaware Estuary & Total saturated & $2.3-492$ & Wehmiller \& Lethen (1975) \\
\hline Tampa Bay, Florida & Total & $0.3-10.5$ & Van Vleet \& Reinhardt (1983) \\
\hline NE Gulf of Mexico & Total & $1.5-11.7$ & Gearing et al. (1976) \\
\hline NW Gulf of Mexico & Aliphatics & $13-27$ & Lytle \& Lytle (1979) \\
\hline \multicolumn{4}{|l|}{ Bank of Campeche, Mexico } \\
\hline (Pre Ixtoc-I spill) & Total & $12-56$ & Botello et al. (1982) \\
\hline St. Georges Harbour, Bermuda & Total & 107 & Sleeter et al. (1980) \\
\hline Castle Harbour, Bermuda & Total & 78 & Sleeter et al. (1980) \\
\hline Sue Wood Bay, Bermuda & Total & 42 & Sleeter et al. (1980) \\
\hline Santa Barbara Seep, CA & Total & $1280-3390$ & Spies \& Davis (1979) \\
\hline Isla Vista Seep, CA & Total & $2120-10190$ & Stuermer et al. (1982) \\
\hline San Pedro Basin, CA & Total & 3100 & Venkatesan et al. (1980) \\
\hline San Nicolas Basin, CA & Total & 710 & Venkatesan et al. (1980) \\
\hline Puget Sound, WA & Total aliphatic & $12-360$ & Barrick et al. (1980) \\
\hline Beaufort Sea, Alaska & Total & $20-50$ & Venkatesan \& Kaplan (1982) \\
\hline Cook Inlet, Alaska & Total & $1-39$ & Venkatesan \& Kaplan (1982) \\
\hline Norton Sound, Alaska & Total & $2-29$ & Venkatesan \& Kaplan (1982) \\
\hline \multirow[t]{2}{*}{ Northern Taiwan Strait } & Aromatic & $1-62$ & Jeng $(1978)$ \\
\hline & Aliphatics & $1-63$ & Jeng (1978) \\
\hline Western Taiwan, Estuaries & Total & $1-310$ & Jeng (1981) \\
\hline French Mediterranean & Total & 20 & Mille et al. (1981) \\
\hline \multirow{2}{*}{ River Blyth, UK } & Total lipids & 5240 & Cooper et al. (1974) \\
\hline & Total alkanes & 3320 & Cooper et al. (1974) \\
\hline Severn Estuary, UK & Crude oil & 105 & Thompson \& Eglinton (1978) \\
\hline Southampton Water Estuary, UK & Petroleum & $500-4000$ & Knap \& Williams (1982) \\
\hline Liverpool Bay, UK & Total & $5-340$ & Law $(1981)$ \\
\hline Falmouth Bay, UK & Total & 48 & Law (1981) \\
\hline Firth of Clyde, UK & N-Alkanes, C18-C33 & 0.6 & Mackie et al. (1974) \\
\hline Kalundborg Fjord, Denmark & Petroleum & $19-218$ & Gruttner \& Jensen (1983) \\
\hline Gotland Basin, Baltic & Total & 140 & Law \& Andrulewicz (1983) \\
\hline Gdansk Bay, Baltic & Total & $4-130$ & Law \& Andrulewicz (1983) \\
\hline Pommern Bay, Baltic & Total & 32 & Law \& Andrulewicz (1983) \\
\hline Saudafjord, Norway & Aromatic & 56.1 & Sporstol et al. (1983) \\
\hline Hovland, Norway & Aromatic & 1.5 & Sporstol et al. (1983) \\
\hline Brofjord, Norway & Aromatic & 0.5 & Sporstol et al. (1983) \\
\hline Oslofjord, Norway & Aromatic & $0.6-1.2$ & Sporstol et al. (1983) \\
\hline Southern Finland & Oil & $530-3000$ & Leppäkoski \& Lindström (1978) \\
\hline
\end{tabular}


Alongi et al. 1983) have demonstrated the relative resilience of meiobenthic communities whereas the recovery of macrobenthic communities is usually much slower (Sanders et al. 1980, Oviatt et al. 1982). However, other investigators studying the aftermath of accidental oil spills have shown that the recovery of meiobenthic communities may require longer than found here (Wormald 1976: 15 mo, Bodin \& Boucher 1983: > 2.5 yr, Elmgren et al. 1983: at least 2 yr). This may be expected if the return of a normal meiofaunal community requires a normal macrofaunal community.

\section{PERSPECTIVE}

Our results have shown that the addition of very small amounts of No. 2 fuel oil can alter dramatically the structure and dynamics of benthic meiofaunal communities. It has been demonstrated previously that the results from the MERL oil experiments may be used to predict what would happen in real world ecosystems if the type of petroleum hydrocarbons present are fairly similar (Elmgren \& Frithsen 1982). This leads credence to the use of these results to also predict the effects from long-term, low-level oil inputs to coastal areas, but since a suite of different types of oils is present, the value of such predictions needs testing. However, Teal \& Howarth (1984) in a review of ecosystem level studies of oil spills, have concluded that oil concentrations and environmental conditions are more important determinants of input than the composition of oil.

Many coastal areas are already significantly contaminated with petroleum derived hydrocarbons as has been found by the 'Mussel Watch' program (Farrington et al. 1983) and other studies (Table 3). In many areas, sediment hydrocarbon concentrations equal or exceed the concentrations measured during the MERL experiments. Therefore, we suspect that the meiofaunal communities in such areas may be altered due to the effects of oil. Altered community structure need not be reflected in terms of reduced abundances since populations may adapt to high concentrations of hydrocarbons. Studies of the ecology of meiofauna in urbanized coastal areas should thus address sediment contaminants even in areas not previously impacted by oil spills and tanker and refinery operations, because of the ubiquity of chronic sources of petroleum hydrocarbons.

Acknowledgements. The help of the entire staff of the Marine Ecosystems Research Laboratory is gratefully acknowledged, particularly that of Wes Chesser, Larry Davey, Eric Klos and Susan Brown-Leger who helped with sampling, Sandra Thornton who assisted with the sample analysis, Eric Anderson who assisted with the data management programs, and Ken Morse who helped with completing Table 1. Candace
Oviatt supplied unpublished data from the National Academy of Sciences plenary session on oil in the marine environment. Michael Pilson, Candace Oviatt, Patrick Gearing, Juanita Gearing, and Peter Doering provided helpful comments and criticisms of earlier drafts of the manuscript. This research was supported by the United States Environmental Protection Agency under grants \#R 80392020, \#806072010 and \#806072020 and cooperative agreement \#CR 807795 to the Marine Ecosystems Research Laboratory. This research was conducted in partial fulfillment of the $\mathrm{Ph}$. D. requirements for J. B. Frithsen.

\section{LITERATURE CITED}

Alongi, D. M., Boesch, D. F., Diaz, R. J. (1983). Colonization of meiobenthos in oil-contaminated subtidal sands in the lower Chesapeake Bay. Mar. Biol. 72: 325-335

Atlas, R. M. (1981). Microbial degradation of petroleum hydrocarbons: An environmental perspective. Microb. Rev. 45: $180-209$

Barrick, R. C., Hedges, J. I., Peterson, M. L. (1980). Hydrocarbon geochemistry of the Puget Sound Region - I Sedimentary acyclic hydrocarbons. Geochim. cosmochim. Acta 44: 1349-1362

Bodin, Ph., LeMoal, Y. (1982). Effets a court terme sur la meiofaune et la macrofaune, du nettoyage d'une plage polluee par les hydrocarbures avec utilisation d'un dispersant. Acta Oecologica 3: 263-280

Bodin, Ph., Boucher, D. (1983). Evolution a moyen terme du meiobenthos et des pigments chlorophylliens sur quelques plages polluees par la maree noire de l'Amoco Cadiz. Oceanologica Acta 6: 321-332

Boehm, P. D., Quinn, J. G. (1978). Benthic hydrocarbons of Rhode Island Sound. Estuar. coast. mar. Sci. 6: 471-494

Boehm, P. D., Steinhauer, W. G., Fiest, D. L., Mosesman, N., Barak, J. E., Perry, G. H. (1979). A chemical assessment of the present levels and sources of hydrocarbon pollutants in the Georges Bank region. In: Proceedings 1979 Oil Spill Conference (Prevention, behavior, control, clean-up). American Petroleum Institute Publication No. 4308, Washington, D.C., p. 333-341

Boehm, P. D., Barak, J. E., Fiest, D. L., Elskus, A. A. (1982). A chemical investigation of the transport and fate of petroleum hydrocarbons in littoral and benthic environments: the Tsesis oil spill. Mar. environ. Res. 6: 157-188

Botello, A. V., Castro, S. A., Guerrero, R. (1982). Baseline studies for hydrocarbons and organic carbon isotope ratios of recent sediments in the Bank of Campeche before the Ixtoc-I oil spill. In: Keith, L. H. (ed.) Energy and environmental chemistry: fossil fuels, Vol. 1. Ann Arbor Science, Ann Arbor, Michigan, p. 119-128

Boucher, G. (1980). Impact of Amoco Cadiz oil spill on intertidal and sublittoral meiofauna. Mar. Pollut. Bull. 11: 95-101

Cabioch, L., Dauvin, J. C., Retiere, C., Rivain, V., Archambault, D. (1982). Evolution de peuplements benthiques des fonds sedimentares de la region de Roscoff, perturbes parles hydrocarbures de L'Amoco Cadiz. Neth. J. Sea Res. 16: 491-501

Cantelmo, F. R., Rao, K. R. (1978). Effect of pentachlorophenol (PCP) on meiobenthic communities established in an experimental system. Mar. Biol. 4: 17-22

Chasse, C. (1978). The ecological impact on and near shores by the Amoco Cadiz oil spill. Mar. Pollut. Bull. 9: 298-301

Connell, D. W. (1982). An approximate petroleum hydrocarbon budget for the Hudson Raritan estuary - New York. Mar. Pollut. Bull. 13: 89-93 
Cooper, B. S., Harris, R. C., Thompson, S. (1974). Landderived pollutant hydrocarbons. Mar. Pollut. Bull. 5: 15-16

Davis, P. G., Heffernan, R. E., Sieburth, J. McN. (1979). Heterotrophic microbial populations in estuarine microcosms: influence of season and water-accommodated hydrocarbons. Trans. Am. microsc. Soc. 98: 152

Elmgren, R. (1973). Methods of sampling sublittoral soft bottom meiofauna. Oikos Suppl. 15: 112-120

Elmgren, R., Frithsen, J. B. (1982). The use of experimental ecosystems for evaluating the environmental impact of pollutants: a comparison of an oil spill in the Baltic Sea and two long-term, low-level oil addition experiments in mesocosms. In: Grice, G. D., Reeve, M. R. (ed.) Marine mesocosms: biological and chemical research in experimental ecosystems. Springer-Verlag, New York, p. $109-118$

Elmgren, R., Vargo, G. A., Grassle, J. F., Grassle, J. P., Heinle, D. R., Langlois, G., Vargo, S. L. (1980a). Trophic interactions in experimental marine ecosystems perturbed by oil. In: Giesy, J. P. (ed.) Microcosms in ecological research. DOE Symposium series 52, CONF 781101, NTIS, p. $779-800$

Elmgren, R., Hansson, S., Larsson, U., Sundelin, B. (1980b). Impact of oil on deep soft bottoms. In: Kineman, J. J., Elmgren, R., Hansson, S. (ed.) The Tsesis oil spill: report of the first year scientific study (October 26, 1977 to December 1978). U.S. Department of Commerce, Office of Marine Pollution Assessment, NOAA, Boulder, Colorado, p. $97-126$

Elmgren, R., Hansson, S., Larsson, U., Sundelin, B., Boehm, P. D. (1983). The 'Tsesis' oil spill: acute and long-term impact on the benthos. Mar. Biol. 73: 51--65

Eskin, R. (1980). The community structure of intertidal nematodes in areas of variable chronic low level oil pollution. MA Thesis, Hofstra University, Hempstead, New York.

Farrington, J. W., Quinn, J. G. (1973). Petroleum hydrocarbons in Narragansett Bay. I. Survey of hydrocarbons in sediments and clams (Mercenaria mercenaria). Estuar. coast. Mar. Sci. 1; 71-80

Farrington, J. W., Tripp, B. W. (1977). Hydrocarbons in western North Atlantic surface sediments. Geochim. cosmochim. Acta 41: 1627-1641

Farrington, J. W., Goldberg, E. D., Risebrough, R. W., Martin, J. H., Bowen, V. T. (1983). U.S. 'Mussel Watch' 1976-1978: an overview of the trace-metal, $\mathrm{DDE}, \mathrm{PCB}$, hydrocarbon, and artificial radionuclide data. Environ. Sci. Technol. 17: $490-496$

Fenchel, T. (1967). The ecology of marine microbenthos 1 . The quantitative importance of ciliates as compared with metazoans in various types of sediments. Ophelia 4: 121-137

Fleeger, J. W., Chandler, G. T. (1983). Meiofauna responses to an experimental oil spill in a Louisiana salt Marsh. Mar. Ecol. Prog. Ser. 11: 257-264

Frithsen, J. B. (1984). Ecological studies of meiofauna in mesocosms. Ph. D. Dissertation, Graduate School of Oceanography, University of Rhode Island, Kingston, Rhode Island

Frithsen, J. B., Rudnick, D. T., Elmgren, R. (1983). A new, flow-through corer for the quantitative sampling of surface sediments. Hydrobiologia 99: 75-79

Gearing, P. J., Gearing, J. N. (1982a). Behaviour of No. 2 fuel oil in the water column of controlled ecosystems. Mar environ. Res. 6: 115-132

Gearing, P. J., Gearing, J. N. (1982b). Transport of No. 2 fuel oil between water column, surface microlayer and atmosphere in controlled ecosystems. Mar environ. Res. 6: 133-143

Gearing, J. N., Gearing, P. J. (1983). Suspended load and solubility effect on sedimentation of petroleum hydrocarbons in controlled estuarine ecosystems. Can. J. Fish. aquat. Sci. 40 (Suppl. 2): 54-62

Gearing, P., Gearing, J. N., Lytle, J. F., Lytle, J. S. (1976). Hydrocarbons in 60 northeast Gulf of Mexico shelf sediments: a preliminary survey. Geochim. cosmochim. Acta 40: $1005-1017$

Gearing, J. N., Gearing, P. J., Lytle, J. F., Lytle, J. S. (1978), Comparison of thin layer and column chromatography for separation of sedimentary hydrocarbons. Analyt. Chem. 50: $1833-1836$

Gearing, J. N., Gearing, P. J., Wade, T., Quinn, J. G., McCarty, H. B., Farrington, J., Lee, R. F. (1979). The rates of transport and fates of petroleum hydrocarbons in a controlled marine ecosystem, and a note on analytical variability. In: Proceedings of the 1979 oil spill conference (Prevention, behavior, control, cleanup). Publication No. 4308, American Petroleum Institute, Washington, D.C., p. $555-564$

Gearing, P. J, Gearing, J. N., Pruell, R. J., Wade, T. L., Quinn, J. G. (1980). Partitioning of No. 2 fuel oil in controlled estuarine ecosystems: sediments and suspended particulate matter. Environ. Sci. Technol. 14: 1129-1136

Giere, O. (1979). The impact of oil pollution on intertidal meiofauna. Field studies after the La Coruna spill, May 1976. Cah. Biol. mar. 20: 231-251

Giesy, J. P. (ed.) (1980). Microcosms in ecological research DOE Symposium Series 52, CONF 781101, NTIS

Grassle, J. F., Elmgren, R., Grassle, J. P. (1981). Response of benthic communities in MERL experimental ecosystems to low-level chronic additions of No. 2 fuel oil. Mar. environ. Res. 4: 279-297

Grice, G. D., Reeve, M. R. (ed.) (1982). Marine mesocosms: biological and chemical research in experimental ecosystems. Springer-Verlag, New York

Gruttner, H., Jensen, K. (1983). Effects of chronic oil pollution from refinery effluent on sediment microflora in a Danish coastal area. Mar. Pollut. Bull. 14: 456-459

Hicks, G. R. F. (1982). Habitat structure, disturbance, and equilibrium in crustacean communities. P.S.Z.N.I. Mar. Ecol. 3: 41-51

Hoffman, E. J., Mills, G. L., Latimer, J. S., Quinn, J. G. (1983). Annual input of petroleum hydrocarbons to the coastal environment via urban runoff. Can. J. Fish. aquat. Sci. 40 (Suppl. 2): 41-53

Hurtt, A. C., Quinn, J. G. (1979). Distribution of hydrocarbons in Narragansett Bay sediment cores. Environ. Sci. Technol. 13: 829-836

Hyland, J. L., Schneider, E. D. (1976). Petroleum hydrocarbons and their effect on marine organisms, populations, communities and ecosystems. In: Sources, effects and sinks of hydrocarbons in the aquatic environment. American Institute of Biological Sciences, Washington, D.C. p. $463-506$

Jeng, W.-L. (1978). Hydrocarbons in the surface sediments of northern Taiwan Strait. Acta Oceanog. Taiwan 8: 80-86

Jeng, W.-L. (1981). Aliphatic hydrocarbons in river and estuarine sediments of western Taiwan. Acta Oceanog. Taiwan 12: 16-27

Kineman, J. J., Elmgren, R., Hansson, S. (ed.) (1980). The Tsesis oil spill: report of the first year scientific study (October 26, 1977 to December 1978). U.S. Department of 
Commerce, Office of Marine Pollution Assessment, NOAA, Boulder, Colorado

Knap, A. H., Williams, P. J. LeB. (1982). Experimental studies to determine the fate of petroleum hydrocarbons from refinery effluent in an estuarine system. Environ. Sci. Technol. 16: 1-4

Koons, C. B., Thomas, J. P. (1979). C15+ hydrocarbons in the sediments of the New York Bight. In: Proceedings, 1979 Oil Spill Conferences (Prevention, Behavior, Control, Cleanup). American Petroleum Institute Publication No. 4308 , Washington, D.C., p. $625-628$

Langlois, G. A. (1980). The effect of pollutant stress on microbial interactions in the marine benthic environment: Field studies and experimental ecosystems. In: The fate and effects of chronic low level pollutants in marine ecosystems, Report for Year II of EPA Grant \#806072020, Marine Ecosystems Research Laboratory, Univ. of Rhode Island, Kingston, p. 208-234

Larsen, P. F., Gadbois, D. F., Johnson, A. C., Doggitt, L. F. (1983). Distribution of polycyclic aromatic hydrocarbons in the surficial sediments of Casco Bay, Maine. Bull. environ. Contam. Toxicol. 30: 530-535

Law, R. J. (1981). Hydrocarbon concentrations in water and sediments from UK marine waters, determined by fluorescence spectroscopy. Mar. Pollut. Bull. 12: 153-157

Law, R., Andrulewicz, E. (1983). Hydrocarbons in water, sediment and mussels from the southern Baltic Sea. Mar. Pollut. Bull. 14: 289-293

Leppäkoski, E. J., Lindström, L. S. (1978). Recovery of benthic macrofauna from chronic pollution in the sea area off a refinery plant, southwest Finland. J. Fish. Res. Bd Can. 35: $766-775$

Levy, E. M., Ehrhardt, M. (1981). Natural seepage of petroleum at Buchan Gulf, Baffin Island. Mar. Chem. 10: 355-364

Linden, O. (1976). Effects of oil on the amphipod Gammarus oceanicus. Environ. Pollut. 10: 239-250

Lytle, T. F., Lytle, J. S. (1979). Sediment hydrocarbons near an oil rig. Estuar. coast. mar. Sci. 9: 319-330

Mackie, P. R., Whittle, K. J., Hardy, R. (1974). Hydrocarbons in the marine environment. I. n-Alkanes in the Firth of Clyde. Estuar. coast. mar. Sci. 2: 359-374

McLachlan, A., Harty, B. (1982). Effects of crude oil on the supralittoral meiofauna of a sandy beach. Mar. environ. Res. 7: 71-79

Mann, K. H., Clarke, R. B. (1978). Long-term effects of oil spills on marine intertidal communities. J. Fish. Res. Bd Can. 35: 791-795

Marcotte, B. M., Coull, B. C. (1974). Pollution, diversity and meiobenthic communities in the north Adriatic (Bay of Piran, Yugoslavia). Vie Milieu 24: 281-300

Mille, G., Dou, H., Cristiani, G., Guisti, G. (1981). Hydrocarbures presents dans des sediments cotiers superficiels Mediterraneens I: Etude qualitative et quantitative fine. Environ. Pollut. (Ser. B) 2: 437-450

National Academy of Science (1975). Petroleum in the marine environment. Workshop on inputs, fates, and the effects of petroleum in the marine environment, May 21-25, 1973. National Academy of Sciences, Washington, D.C.

National Academy of Science (1985). Petroleum in the marine environment. National Academy of Sciences, Washington, D.C., in press

Neff, J. M., Anderson, J. W. (1981). Responses of marine animals to petroleum and specific petroleum hydrocarbons. Wiley, New York

Nixon, S. W., Alonso, D., Pilson, M. E. Q., Buckley, B. A. (1980). Turbulent mixing in aquatic microcosms. In:
Giesy, J. P. (ed.) Microcosms in ecological research. DOE Symposium Series 52, CONF 781101, NTIS, p. 818-849

Oviatt, C. A., Walker, H., Pilson, M. E. Q. (1980). An exploratory analysis of microcosm and ecosystem behavior using multivariate techniques. Mar. Ecol. Prog. Ser. 2: 179-191

Oviatt, C., Buckley, B., Nixon, S. (1981). Annual phytoplankton metabolism in Narragansett Bay calculated from survey field measurements and microcosm observations Estuaries 4: 167-175

Oviatt, C., Frithsen, J., Gearing, J., Gearing, P. (1982). Low chronic additions of No. 2 fuel oil: chemical behavior, biological impact and recovery in a simulated estuarine environment. Mar. Ecol. Prog. Ser. 9: 121-136

Parsons, T. R., Jansson, B. O., Longhurst, A. R., Saetersdal, G. (ed.) (1978). Marine ecosystems and fisheries oceanography. Rapp. P.-v. Réun. Cons. int. Explor. Mer 173: 1-240

Pequegnat, W. E. (1975). Meiobenthos ecosystems as indicators of the effects of dredging. In: Cronin, L. E. (ed.) Estuarine research. Academic Press, New York, p. $573-584$

Percy, J. A. (1977). Responses of arctic marine benthic crustaceans to sediments contaminated with crude oil. Environ. Pollut. 13: 1-10

Pilson, M. E. Q. (1985). On the residence time of water in Narragansett Bay. Estuaries 8 (in press)

Pilson, M. E. Q., Oviatt, C. A., Nixon, S. W. (1980). Annual nutrient cycles in a marine microcosm. In: Giesy, J. P. (ed.) Microcosms in ecological research. DOE Symposium Series 52, CONF 781101, NTIS, p. 753-778

Renaud-Mornant, J., Gourbault, N., de Panafiew, J. B., Helleouet, M. N. (1981). Effects de la pollution par hydrocarbures sur la meiofaune de la baie de Morlaix. In: Amoco Cadiz, consequences d'une pollution accidentelle par les hydrocarbures. Actes Coll. Intern. C.O.B. Brest (France). 19-22 Nov. 1979, p. 551-561

Rutzler, K., Sterrer, W. (1970). Oil pollution: Damage observed in tropical communities along the Atlantic seaboard of Panama. BioScience 20: 222-224

Sanders, H. L., Grassle, J. F., Hampson, G. R., Morse, L. S., Garner-Price, S., Jones, C. C. (1980). Anatomy of an oil spill: long-term effects from the grounding of the barge Florida off West Falmouth, Massachusetts. J, mar. Res. 38: 265-380

SAS (1982). SAS statistics user guide. SAS Institute, Inc., Cary, North Carolina

Sleeter, T. D., Butler, J. N., Barbash, J. E. (1980). Hydrocarbons in the sediments of the Bermuda Region: lagoonal to abyssal depths. In: Petrakis, L., Weiss, F. T. (ed.) Petroleum in the marine environment. Advances in Chemistry Series 185, American Chemical Society, Washington, D.C., p. $268-288$

Snedecor, G. W., Cochran, W. G. (1967). Statistical methods, 6 th ed. Iowa State Univ. Press, Ames, Iowa

Spies, R. B., Davis, P. H. (1979). The infaunal benthos of a natural oil seep in the Santa Barbara Channel. Mar. Biol. 50: $227-237$

Sporstol, S., Gjos, N., Lichtenthaler, R. G., Gustavsen, K. O., Urdal, K., Oreld, F., Skel, J. (1983). Source identification of aromatic hydrocarbons in sediments using GC/MS. Environ. Sci. Technol. 17: 282-286

Stainken, D. (1979). Ocurrence of extractable hydrocarbons in sediments from Raritan Bay, New Jersey. Bull. N. J. Acad. Sci. 24: 6-11

Stuermer, D. H., Spies, R. B., Davis, P. H., Ng, D. T., Morris, C. J., Neal, S. (1982). The hydrocarbons in the Isla Vista marine seep environment. Mar. Chem. 11: 413-426 
Teal, J. M., Howarth, R. W. (1984). Oil spill studies: a review of ecological effects. Environ. Manag. 8: 27-44

Thompson, S., Eglinton, G. (1978). Composition and sources of pollutant hydrocarbons in the Severn estuary. Mar. Pollut. Bull. 9: 133-136

Uhlig, G., Thiel, H., Gray, J. S. (1973). The quantitative separation of meiofauna. A comparison of methods. Helgoländer wiss. Meeresunters. 25: 173-195

Van Vleet, E. S., Quinn, J. G. (1977). Input and fate of petroleum hydrocarbons entering the Providence River and upper Narragansett Bay from wastewater effluents. Environ. Sci. Technol. 11: 1086-1092

Van Vleet, E. S., Quinn, J. G. (1978). Contribution of chronic petroleum inputs to Narragansett Bay and Rhode Island Sound sediments. J. Fish. Res. Bd Can. 35: 536-543

Van Vleet, E. S., Reinhardt, S. B. (1983). Inputs and fates of petroleum hydrocarbons in a subtropical marine estuary. Environ. Int. 9: 19-26

Vargo, G. A., Hutchins, M., Almquist, G. (1982). The effects of low, chronic levels of No. 2 fuel oil on natural phytoplankton assemblages in microcosms: 1. Species composition and seasonal succession. Mar. environ. Res. 6: 245-264

Venkatesan, M. I., Kaplan, I. R. (1982). Distribution and transport of hydrocarbons in surface sediments of the Alaskan outer continental shelf. Geochim. cosmochim. Acta 46 : 2135-2149

Venkatesan, M. I., Brenner, S., Ruth, E., Bonilla, J., Kaplan, I. R. (1980). Hydrocarbons in age-dated sediment cores from two basins in the Southern California Bight. Geochim. cosmochim. Acta 44: 789-802

Wade, T., Quinn, J. Q. (1979). Geochemical distribution of hydrocarbons in sediments from mid-Narragansett Bay, Rhode Island. Org. Geochem. 1: 157-167

Wade, T. L., Quinn, J. G. (1980). Incorporation, distribution, and fate of saturated petroleum hydrocarbons in sediments from a controlled ecosystem. Mar. environ. Res. 3: $15-33$

Walker, J. D., Colwell, R. R., Hamming, M. C., Ford, H. T, (1975). Petroleum hydrocarbons in Baltimore Harbour of Chesapeake Bay: distribution in sediment cores. Environ. Pollut. 9: 231-238

Wehmiller, J. F., Lethen, M. (1975). Saturated hydrocarbon material in sediments of the Delaware estuary as deter. mined by gas chromatographic analyses. College of Marine Studies, Univ. Delaware, Newark, Delaware

Wormald, A. P. (1976). Effects of a spill of marine diesel oil on the meiofauna of a sandy beach at Picnic Bay, Hong Kong. Environ. Pollut. 11: 117-130 